\title{
Ion Diyaloğu: Bir Rhapsodos Hikâyesi
}

\author{
Ion Dialogue: The Story of a Rhapsodos
}

\begin{abstract}
Nihal Petek BOYACI *
Öz: Platon'un en kısa diyalogları arasında yer alan Ion, gerek diyaloğun konusu gerekse erken dönem diyaloglarından farklı bir biçime sahip olmasından dolayı uzunca bir zaman Platon'a ait olup olmadığı belli olmayan diyaloglar arasında sınıflandırılmıştır. Bu durum diyaloğun önemsiz görülmesine ve üzerinde konuşulmasının ve tartışılmasının gereksiz olduğu düşüncesine yol açmıştır. Bu makalede Platon'un bu diyaloğunun önemi vurgulanacak ve diyaloğun Platon’un yalnızca estetik anlayışını değil aynı zamanda bilgi görüşünü de sunduğu, böylece diğer diyalogları arasında önemli bir yere sahip olduğu gösterilmeye çalışılacaktır. Giriş kısmında Ion'un Platon'a ait bir diyalog olarak kabul edilip edilemeyeceği tartışması yürütülecek ve konuyla ilgili farklı görüşlere yer verilecektir. İlk bölümde diyaloğun nasıl bölümlenebileceği ve temel probleminin ne olduğu açıklanacak ve ikinci bölümde diyaloğun tartışma konularından biri olan tekhnê kavramı ayrıntılı bir biçimde ele alınacak ve kavramın özellikleri belirlenecektir. Üçüncü bölüm ise Ion’un (veya bir rhapsodos'un) şair(ler)i yorumlamasının nasıl gerçekleştiği ve Platon’un neden şiire, şairlere ve rhapsodos'lara olumsuz bir biçimde davrandığı tartışılacaktır.
\end{abstract}

Anahtar sözcükler: Platon, Tekhnê, Esinlenme, Şiir, Theia Moira

Abstract: For a long time, Ion, one of the shortest dialogues of Plato, was classified as mongst those dialogues the author of which remained controversial, both because of its subject and different style when compared to other early dialogues. This has resulted in the idea that this dialogue was indeed insignificant and even unnecessary to read and discuss. In this article, the importance of this dialogue is shown and also the attempt is made to show that this dialogue exhibits not only the Plato's understanding of aesthetic, but also his idea of knowledge. In the introduction, a discussion of whether or not Ion can be accepted as a written dialogue by Plato will be made by allowing different ideas. The first part, explains how the dialogue can be divided and what the dialogue's main problem or discussion concerns. In the second part, the concept of technê, which is one of the main discussions of the dialogue, is discussed in detail and the characteristic of the technê is indicated. Third part discusses how Ion (or a rhapsods) interprets the poet(s) and why Plato treats the poets and rhapsods and poems negatively.

Keywords: Plato, Technê, Inspiration, Poetry, Theia Moira

\section{Giriş}

Platon'un en kısa diyaloglarından biri olan Ion, edebi bilginin doğasını sorgulayan ilk metin olarak görülebilir (Liebert 2010, 179). Diyaloğun kısalığ1 içeriğinin yoğunluğuna engel teşkil etmemekle beraber, her satırı şiir, şair ve rhapsodos’larla ilgili önemli tartışmalara giriş niteliği taşımaktadır. Ancak Ion kimi zaman okuması keyifli bir diyalog olarak adlandırılsa da, bazı Platon yorumcuları tarafından, filozofun diğer diyalogları kadar önemli görülmez ve hatta Pla-

\footnotetext{
* Dr. Öğr. Ü., İstanbul Medeniyet Üniversitesi, Güney Kampüsü, Edebiyat Fakültesi, Felsefe Bölümü, İstanbul. npetekb@gmail.com, petek.boyaci@medeniyet.edu.tr
} 
ton'un sahte diyaloglarından biri olarak değerlendirilir. Ritter, Ast ve Zeller gibi Platon yorumcuları diyaloğun dilsel yapısı dolayısıyla sahte olduğunu iddia etmektedirler (Zeller 1888, 86; Guthrie 1975, 199). Schleiermacher ise yine bu diyaloğun doğrudan Platon'a ait olmadığını ya da Platon'un kendisi tarafından değil de, bir öğrencisi tarafından tamamlanan kısa bir güldürü olabileceği ihtimali üzerinde durur (Moore 1974, 421). Wilamowitz diyaloğun sahte olduğu fikrini kabul etmemekle birlikte diyaloğu "acemi bir çaylak teşebbüsü" olarak tanımlar (Guthrie 1975, 199), düşünür buna ek olarak Ion'u Platon'un diğer diyaloglarına göre daha zayıf ve kafa karıştıcı olarak nitelemekle kalmaz, bir diyalogdan ziyade basit bir hiciv olarak görür (Moore 1974, 421).

Ion diyaloğu Sokrates'in Savunması'ndan (Apologia Sokratous) hemen sonrası bir tarihe, MÖ 390 yılına, Platon'un politik kariyer umutlarını yavaş yavaş terk etmeye başladığı ve tam zamanlı bir filozof olmaya karar vermeden hemen önceki dönemine tekabül eder. Diyaloğun tarihlemesi Sokratik söylemin tam bir şekle bürünmesinden daha önceki bir zamana yapılır (Kahn 1998, 101). Ancak diyaloğun daha önceki bir zamana, Sokrates’in ölümünden sonraki bir zamana, MÖ 394-391'e tarihlendirilebileceği de yine ileri sürülen bir diğer iddiadır (Guthrie 1975, 199). Diyaloğun acemice yazıldığını düşünenen Wilamowitz ise Ion'u, çok daha erken bir zamana ait olduğunu ileri sürerek MÖ 399’a tarihlendirir.

Günümüzde Ion'un Platon'un diğer diyaloglarıyla pek çok açıdan benzerlik gösterdiği düşünülmekle birlikte, erken (gençlik/sokratik) dönem diyaloglarıyla karşılaştırıldığında yapısal olarak bir karışıklık göstermesi sebebiyle bu eser farklılık arz eder. Bilindiği üzere, erken dönem diyalogları herhangi bir çözümle veya kesin bir tanımlamayla (aporia) sonuçlanmaz. Oysa Ion diyaloğu bu açıdan bakıldığında kesin bir tanımlamayla son bulur. Diyaloğun temel araştırma konusu çözüme ulaşmıştır ve diyaloğun hemen başında ele alınan sorular yanıtsız bırakılmamıştır (Barchana-Lorand 2012, 85). Ayrıca erken dönem diyaloglarında görülen, karş1lıklı kısa diyalog ve soru-cevap biçiminde devam eden uslübün Ion' da bulunmadığı söylenebilir. Platon, bu kısa eserde konudan konuya geçişler yaparak diyalogdan ziyade, çoğu zaman uzun konuşmaların yer aldığı bir monolog tarzıyla karşımıza çıkar. Oysa bu özellik daha çok filozofun orta veya geç dönem diyaloglarında görülmektedir (Barchana-Lorand 2012, 85). Barchana-Lorand bu özelliklerin diyaloğun yapısal olarak farklı olduğu ve hatta Platon'un kendi diyalogları arasında yer almaması gerektiği iddiasını desteklemekten ziyade, diyaloğun özüne ilişkin önemli bir ayrıntıyla yakından ilişkili olduğunu düşünmektedir. Ona göre, Platon şiirsel söylemle ilgili bir kararsızlık yaşamaktadır (Barchana-Lorand 2012, 85). Şairin bir eser ortaya çıkarması onun rasyonel biri olmamasıyla ilişkilendirilir (Pl. Ion 534). Şairin bilmesinin nasıl bir bilme olduğunu gösterme çabası bağlamında temeli sağlam olmayan ve şiirin bizzat kendisinin zayıf epistemik referanslara sahip olması, onu mantıksal düşünme sonucunda bir çıkarımda bulunmaktan uzaklaştırır. Şiir kimi zaman doğru sanı ortaya koyuyor ve hatta sanıyı gerekçelendirebilse bile, bu, şiirdeki bilmenin rasyonel düşünmeyle eş değer olduğunu göstermez. Platon da Ion diyaloğunda tam anlamıyla bu ikilemi yaşamaktadır. Bu nedenle BarchanaLorand'a göre Ion diyaloğunun farklılığının konusuyla yakından ilgili olduğunu söylemek yanlış olmayacaktır.

Platon'un Politeia diyaloğunda şiir ve şairlerle ilgili önemli belirlemeler yapması ve onların hakikat açısından değerini tartışmaya açması, hatta ideal devlet düzeni içinde söz konusu sanatçılara eleştirel yaklaşarak onların neredeyse toplumda yer almasını sakıncalı görmesi, daha önceki döneme tarihlenen Ion diyaloğunun önemini ortadan kaldırmış olabilir. Buna göre, bir devlet düzeni içinde şiirin önemli bir yer teşkil etmiyor oluşu, şiirle ve onu icra edenlerle ilgili herhangi bir tartışmayı da gerektirmeyecektir. Bu nedenle şair, rhapsodos ve şiir kavramlarıyla 
ilgili derinlikli tartışmalara gerek yoktur (Barchana-Lorand 2012, 86). Nomoi adlı eserinde tartışılan şiirin bir devlet düzeninde nasıl bir yeri olabileceği tartışmasında Ion diyaloğu daha önemli bir yer kaplarken, Politeia diyaloğu onun önemini büsbütün ortadan kaldırmıştır (Partee'den akt. Barchana-Lorand 2012, 86). Şiirin epistemik açıdan hiçbir önemi yoksa mahiyetinin ne olduğunu tartışmanın da bir anlamı olmayacaktır. Tüm bunlara göre, Ion'dan sonraki diyalogların, özellikle de Politeia'nın şiiri ele alış tarzı nedeniyle Ion diyaloğunun önemini kaybetmiş olduğu söylenebilir. Ancak bu diyaloğun bizzatihi önemsiz olarak görülmesini de gerektirmez.

\section{Dikkatlice okuyun, Platon'un "başlı başına şiiri"n değerini, epistemik statüsünü, metafizik özünü ve psikolojik gücünü tartışarak Tanrlsal il- hamın otoritesi ve onun fani - yazınsal sanat - eseriyle ilgili olan Pla- ton'un ikileminin canlı bir kesitini vererek ele aldığ vazgeçilmez diyalo- ğudur (Barchana-Lorand 2012, 86).}

Bazı yorumcular, konu ve düşünce yapısı bağlamında, diyaloğun Platon’un daha sonraki diyaloglarıyla uyum içinde olduğunu ileri sürerler (Moore 1972, 422). Buna göre Platon tekhnê ve epistemê ile theia moira arasındaki karşıtlığı (Ion 533d) Menon ve Phaidros diyaloglarında da ele almaktadır. Menon diyaloğunda yapılan erdem tartışmasında (99e) erdemin ne doğal ne de öğretilebilir olduğu, onu ancak theia moira ile edinebileceğimiz dile getirilirken, erdemin doğasının bilgi değeri açısından Ion'un rhapsadosluğu ile eşdeğer olduğu açıkça görülebilir. Phaidros diyaloğunda da yine aynı benzerlikten bahsedilir. Aklı başında olmamaklık yani rasyonel bir biçimde düşünememe epistêmê olarak kabul edilmez, bu ancak theia moira'dır (Pl. 244a244e). Adı geçen diyaloglarda Ion diyaloğunun temel konusuna, yani şairlerin tanrısal esinlenmenin kaynağı olan haberciler olduğuna değinildiği de görülür (Men. 99c -100a; Phdr. 244a245a). Ayrıca pratik eylemle poietik eylem ve poietik olanla rhetorik olan arasındaki fark da yine ortak olan diğer tartışma konuları arasındadır. Moore'a göre, bu tartışmalardan ilki, yani şairlerin haberciler olması, Ion (532c) ile Politeia (600c-d) diyalogları arasında ortaklaşırken, Ion'un 536e-541b satırlarındaki rhetorik tartışmas1, Protagoras (312a vd.), Gorgias (448a vd) diyaloglarındaki tartışmayla ortaklaşmaktadır (Moore 1972, 422).

Tüm bunların yanı sıra, Ion diyaloğu kendisinden önceki bir döneme tarihlenen Sokrates'in Savunması'nda bahsi geçen bir konunun kısa ama derinlikli bir incelemesi olarak düşünülebilir. Bilindiği üzere, Sokrates'in Savunması'nda kendisinin bilge olmadığını ispatlamaya çalışan Sokrates, önce politikacılarla daha sonra da şairlerle konuşma yapmış ve onların da aslında hiçbir şeyi bilmeden anlattıkların fark ettiğini söylemiştir. Sokrates'in Savunması'ndan hemen sonrasına tarihlenen Ion diyaloğunun ana konusunun rhapsodos'lar üzerinden şairleri içermesi ve onların işlerini bilerek mi yoksa bilmeden mi yaptıkları tartışmasının peşine düştüğünün bir göstergesi olarak değerlendirilebilir. Ion diyaloğunun ana teması Platon'un genel felsefi düşüncesi içinde farklı diyaloglarında tartışılan önemli ayrımları görmemizi sağlayan bir konudur. Genel anlamılla epistêmê, tekhnê ve theia moira terimlerinin ne olduğunun araştırılması pek çok farklı diyalogda da gözlemlenebilir. Ion diyaloğunda bu tartışmalar oldukça temel düzeyde yapılmaktadır. Bu nedenle diyalog yalnızca estetik bir anlayış sunan eser olarak değil, aynı zamanda Platon'un bilgi problemine bir giriş metni olarak ele alınmalıdır.

\section{Diyaloğun Bölümlenmesi ve Temel Problemi}

Diyalog Allen (1996, 3-7) ve Dorter'ın $(1973,65)$ yapmış oldukları bölümleme birleştirilerek şu şekilde yapılabilir.

\section{0a-d Giriş}


530d-533c Sanat aynı konuyla ilgili iyi veya kötü konuşanın bilgisi anlamına gelir ve sanatın yetenek (tekhnê) ve bilimden (epistêmê) farklı olarak, onların dışında, evrensel olarak uygulanabilir ilkelerden oluşmadığ 1 gösterilir. Bunun sonunda Ion’un bir sanata sahip olmadığ 1 sonucuna ulaş111r.

533c-536d Şiir ve tanrısallığa sahip olma konusu ele alınırken rhapsodos'ların habercilerin habercisi olarak tanımlandığı görülür. Bu bölümde her ne kadar pozitif önermeler ele alınsa da, belirsiz kısımlar yoğunluktadır.

536d-542b İlk bölümdeki argümanın üzerinde durulur ve sanatın ne olduğu tartışması onu nesneleriyle tanımlama üzerinden yapılarak, sanatın ontolojik temeli ortaya konur.

541e-542b Sonuç. Ion tanrısaldır ve Homeros üzerine usta bir sanatkâr değildir.

Birinci ve üçüncü bölüm berrak bir soru-cevap tarzı içinde özenli ve dikkatlice bir tartışmayı içermektedir. Ancak ikinci bölüm Sokrates tarafından yapılan uzun, mistik ve mecazi konuşmalardan oluşmaktadır (Dorter 1973, 65).

Diyalog, Ion’un Epidauros’taki Asklepieios şenliğinden geldiği sırada Sokrates ile karşılaşmasıyla başlar. Ion bu şenlikteki yarışmada birincilik almış olan bir rhapsodos'tur. Rhapsodos’luk MÖ V. yüzyılda oldukça popüler bir iştir ve şehirden şehre dolaşıp şairlerin (hatta yalnızca belli bir şairin) şiirlerini ezberden okuyarak profesyonel gösteri yapan kimselerin mesleğidir. Rhapsodos sözcügü etimolojik olarak iki kökenle ilişkilendirilmektedir. Bunlardan ilki, rhapsodos'ların gösterilerini elinde asalarına dayalı olarak sergilemelerinden dolayı, asa veya

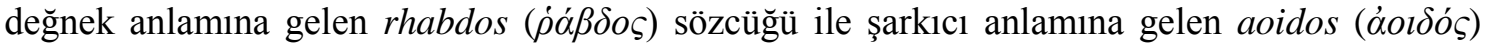
sözcüklerinin birleşiminden ortaya çıkmış bir sözcük olduğu belirlemesidir (Gentile 2008, 154). Bunun dışında kelimenin rhaptô ( $\dot{\rho} \alpha \dot{\pi} \tau \omega)$ ve ôdê ( $\dot{\omega} \delta \dot{\eta})$ sözcüklerinin birleşiminden oluştuğu da söylenebilir. Dikiyorum, ya da dikerek iliştiriyorum anlamına gelen rhaptô ile şarkı, türkü veya kaside anlamına gelen ôdê sözcügünün birleşmesinden şarkıyı veya şiirleri birbirine bağlayan kimse manasında rhapsôdos sözcügünün ortaya çıktığı düşünülmektedir. Rhapsodos'lar üzerlerinde renkli ve süslü kıyafetler (Pl. Ion 530d), başlarında bir taçla küçük bir sahne (bêma) üzerinde büyük bir kitleye şiirleri ezberden okuyarak performanslarını sergilemektedirler (Boyd 1994, 111). Eski Yunancayı tonlayarak okumanın yanı sıra sesini alçaltıp yükselterek konuşmalarından dolayı böylesi bir performans müzikale oldukça benzer bir hâl almaktadır (Allen 1996, 3). Seyircileri duygu seli içinde büyüleyen Ion aslında aynı zamanda oyunculuk da yapmaktadır. Ion'un yaptı̆g 1 iş diyalogda, şairin fikirlerini dinleyicilere yorumlama (hermêneus) gösterisi (Pl. Ion 530c) olarak özetlenir. Ion, yalnızca Homeros'un şiirlerini yorumlamada ustadır (deinos). Diyalogdaki temel tartışma konusu da buradan çıkar. Çünkü Sokrates’e göre, yorumladığı şairin esasen ne söylediğini bilmeden (mê gignôskonta) bunu güzel bir biçimde yapması imkânsızdır (Pl. Ion 530c). Dolayısıyla Ion eğer bir sanat icra ediyorsa, bunu bilerek yapmalıdır. Diyalog bu noktada epistemik bir zemine kayar ve esasen tekhnêlepistêmê ve theia moira arasında bir ayrım yapma yoluna gider. Burada Sokrates tekhnê ile epistêmê arasında bir farklılık gözetmez, çünkü henüz bu iki kavram birbirinin yerine de kullanılabilir durumdadır ve bir şeylerin bilinmesine dair işaret olarak bu iki kavram kullanılmaktadır. Sokrates de konuşmasında henüz epistêmê ve tekhnê arasında ayrım yapma çabası içine girmez. Göstermeye çalıştığ 1 şey Ion'un icra ettiği performansın bu iki bilme biçimiyle gerçekleşmediğidir (Pl. Ion 532c). Diyalog tam da tekhnê ya da epistêmê olsun bilmeyi theia moira'dan ayırma çabası olarak Platon'un diyalogları arasında önemli bir yer tutmaktadır. Sokrates, şairlerin ve rhapsodos'ların bir sanata sahip olup olmadıklarına dair bir araştırma yoluna girerek, Sokrates'in Savunması'nda giriştiği işi sürdürür ve diyalogda açık bir biçimde şairlerin aslında işlerini bilmeden icra ettiklerini, bir sanatla değil, tanrısal ilhamla şiirlerini ortaya çıkardıklarını belirtir. 
Ancak söylemem gerek ne yazık ki; Dünyada bulunanların hemen hemen hepsi kendi eserleri hakkında, mutlaka daha iyi bir lakırdl edebilirdi herhalde. Böylece yine kisa bir sürede, şiirlerini bilgelikle değil, ancak doğalarından kaynaklanan bir şeyle ve bir peygamber ya da kahin gibi vecde gelerek yarattıklarını kavramış oldun (Pl. Apol. 22b-22c).

Platon, Sokrates'in Savunması'nda şairlerin bilgisi ile ilgili bir konuyu tartışmaya açmaktadır. $\mathrm{Bu}$ diyalogdan hemen sonrasına tarihlenen Ion'da ise bu konuyla da bağlantılı bir biçimde şairin ve rhapsodos'un yaptığı işin neden tekhnê olamayacağına dair kısa bir tartışma yapmaktadır.

Diyaloğun giriş kısmında, "siz rhapsodos'ların sanatına her zaman imrenirim, Ion. Çünkü bedeninizi süslüyor ve olabildiğince güzel görünüyor olmanız sizi de sanatın bir parçası yapıyor (Pl. Ion 530a)" diyerek rhapsodos'ların sanatı olduğunu kabul ediyormuş gibi görünen Sokrates'in aslında kostümünü, icra ettiği sanatın bir işareti olarak görmesi tam anlamıyla ironi olarak yorumlanmalıdır (Kahn 1998, 105). Çünkü Sokrates doğrudan Ion'un kıyafetinin sanatıyla olan ilişkisiyle ilgilenmemektedir. Onun Homeros'u sanatla mı yorumlayıp yorumlamadığına yönelik bir sorgulamaya giriş yapmakta ve belki de Ion'un bu tartışmaya girmesi için onu rahatlatmaktadır. Ion'un bir sanatı olduğu kabul edildiği takdirde, en önemli işlevinin (ergon), yani nesnesi ve üretiminin, ancak Homeros'un düşüncelerini yorumlamak olduğu söylenebilir (Pl. Ion 530c). O, aslında yalnızca Homeros'u övmektedir (epainetês) (Allen 1996, 3). Diyalog da Ion'un yalnızca Homeros'u yorumlamasının tekhnê olarak kabul edilip edilemeyeceği tartı̧smasıyla derinleşir. Tekhnê'nin tanımlanması bir rhapsodos'un ona sahip olup olmadığını ortaya çıkarmaya yardımcı olacaktır.

\section{Tekhnê Nedir?}

Tekhnê Eski Yunancada sanat ve zanaat kavramını içine alacak biçimde geniş bir anlam yelpazesine sahiptir. Bu kavram her türden ürün elde etme faaliyeti (ergon) olarak tanımlanabilir. Platon'un diyaloglarında tekhnê'nin doğrudan tek bir tanımlaması olduğunu söylemek zordur. Platon tekhnê'ye dair genel bir açıklamada bulunmaz. Bazı diyaloglarında kavramın farklı bir biçimde açıklandığı dahi görülür (Aguirre 2016, 181-182). Örneğin, Protagoras ve Phaidros (274d) diyaloglarında tekhnê'nin tanrısal kaynaklı olduğu öne sürülmektedir.

Bunun üzerine, insan için hangi korumayı bulacă̆ı şaşkınlığı içinde, Hephaistos ve Athena'dan ateş ile birlikte bilgeliği çald - çünkü ateş olmaksızın hiçbir şekilde hiçbir şey elde edilemez ve faydalı olamaz - ve böylece onu insana hediye etti. Insan günlük hayatın bilgeliğini bu şekilde elde etmiş oldu (Pl. Prot. 321c-d).

Ayrıca Platon'un düzenleyici Tanrısı Demiourgos'un aynı zamanda en büyük sanatkâr (tekhnitês) olarak düşünülmesi yine sanatın tanrısal yanına yapılan bir vurgu olarak da görülebilir. Tekhne'nin hem Protagoras hem de Timaios diyaloğunda tanrılardan alınıp insanlara bahşedilmiş bir ergon işlevine sahip olduğu söylenmektedir. Geniş bir çerçeveden tekhnê şöyle tanımlanabilir: Kendisine sahip olan kişinin pratik bir amaca yönelik düzenlenmiş bilgiyi doğru bir biçimde uygulamak adına yetenek ve uzmanlık sahibi olmasıdır (Aguirre 2016, 182). Böylesi bir tanımlama, kavramı tanrısal kökenlerinden kurtararak insanın sahip olduğu bir bilme türüne dönüşür.

Platon'a göre, bir tekhnê tek bir nesneye aittir. Bu nedenle de her bir tekhnê spesifiktir ve özel bir işleve (ergon) sahiptir (Aguirre 2016, 182). Bundan dolayı bir sanat farklı iki veya daha fazla nesneye veya işleve (ergon) sahip olamaz. Platon Politeia'da "yapabilme güçleri farklı olduğu için, sanatların her biri diğerinden farklı değil midir? (...) örneğin, hekimliğin sanatı 
sağllk; kaptanlı̆̆ınki ise denizlerde güvenliktir... (Pl. Pol. 346a)" diyerek, her bir sanata farklı bir işlev yüklemiş olur. Aynı açıklama Ion diyaloğunda da görülmektedir.

Ben sanatların birbirlerinden farklı olduklarını, şu sanatın şu şeylerin, bu sanatın bu şeylerin bilgisi olduğunu söylediğimde sen de buna katılyyor musun? (...) İki sanat aynı şeylerin bilgisi olsa ikisi de bize aynı bilgiyi vereceğine göre birini diğerinden nasll ayırt edebiliriz (Pl. Ion 537c)?”

Bir tekhnê tamamen kendine özgü bir işlevi olduğu ve tek bir nesne alanıyla ilgilendiği takdirde insanlara fayda sağlayabilir. O halde hekimlik sanatıyla bilinen şeyler marangozluk sanatıyla bilinemez (Pl. Ion 537c). Sanatkâr da ancak tek bir alana dair bilgiye sahip olan, o konuda uzmanlaşmış kişidir. Bu nedenle hekim, marangozluk konularını bilemez. Bu iki sanatı bildiğini iddia eden bir kişi ise esasen bir sanata sahip değildir. Buna göre bir etkinliğin tekhnê sayılabilmesi için ilk özellik, tek ve spesifik bir nesne alanına sahip olmasıdır. Ancak sadece bu özelliğe sahip olmak bir alanın sanat sayılabilmesi için yeterli değildir. Sanat aynı zamanda insanlara fayda da sağlamalıdır. Sanata dair fayda tespiti, ilgili sanat alanına ilişkin bir sanatkâr bulunmadığında çıkabilecek sonuçlar irdelenerek yapılabilir. Örneğin, marangoz olmadan ev, hekim olmadan hastalıklara çare bulunamaz. Bizi denizlerden korumak ergon'una sahip kaptan olmadan, güvenli bir deniz yolculuğu yapamayız (Roochnik 1998, 45). Burada anlatılan fayda sanatkârın çıkarını gözetmez. Sanatkâr hangi alanda olursa olsun, yalnızca o sanatın nesnesinin faydasını gözeten bir işleve sahiptir.

- Az önce dile getirdiğimiz tam anlamiyla hekim nedir? Para kazanan biri mi, yoksa hastalart iyileştiren mi? Hekimin gerçekte kim olduğunu söyle.

- Hastalart iyileştiren tabi.

- Kaptan kimdir? Bir gemici midir sadece yoksa gemicilerin başı mı?

- Gemicilerin başı.

- Demek gemide deniz yolculuğu yapmasının, denizci olarak adlandırılmasının

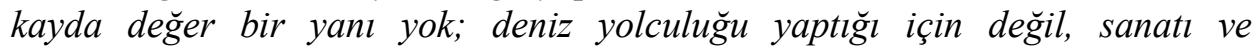
denizcilerin başı olmasından dolayı onu kaptan diye adlandırıyoruz.

- Doğru.

- Peki, onların herbirinin faydasina olan bir şey yok mudur?

- Vardir tabii.

- Sanatın, her biri için, mümkün olduğunca mükemmel olmaktan başka bir faydası olabilir mi (Pl. Pol. 341c-341e)?

Platon bu satırların hemen devamında pek çok farklı sanattan örnek vererek, sanatların yalnızca kendi nesne alanlarıyla ilgili fayda sağladığı konusunu ayrıntılarıyla anlatır. Bir sanat eğer nesnesinin faydasını gözetiyorsa, bu onun ereksel yönü olduğunu gösterir (Roochnik 1998, 141) ve böylece tekhnê'nin ikinci özelliği de belirlenmiş olur. Sanatçı yalnızca konu edindiği nesnesinin faydasına olanı yapar; kendi çıkarını gözetip, nesnesine özensiz davranmaz, onu boşlamaz. Tekhnê'nin ereği budur.

Platon'un tekhnê'nin ne olduğunu tanımlarken ortaya koyduğu bir diğer özellik onu empeiria'dan ayırmasıyla belirlenir. "Tecrübe, marifet, deneyim, görenek, adet, alışkanlık” olarak da Türkçeleştirilebilecek bu kavramın incelemesi, her türden faaliyetin sanat sayılamayacağına dair önemli bir ayrımı gözler önüne sermek açısından önemlidir. Gorgias diyaloğunda bu iki kavram arasındaki fark, empeiria'nın akılla (logos) hareket etmeksizin yalnızca hazza (hêdonê) yönelik bir işlevinin olmasıyla çizilir (Aguirre 2016, 184). Bir diğer deyişle, tekhnê sahibi olmak akılla iş görmeyi ve dolayısıyla nesnesinin durumunu ve doğasını incelemeyi, yaptığı 
şeyin nedenlerini ortaya koymayı gerektirir.

Aşçıllk hekimliğin aksine, bence bir sanat (tekhnê) değil, bir görenektir (empeiria); oysa hekimlik bir sanattır. Hekim, tedavi ettiği insanın özünü ve yaptıklarının nedenini inceler; bunların herbirinin hesabını verir. Aşçıllğın ise verdiği bütün hizmet hazla ilgilidir, hazzın nedenine ve doğasına bakmaz, tamamen akıl-dışıdır; hiçbir şeyi hesaba katmaz (Pl. Grg. 500e-501a).

Aşçılığın hazza yönelik icrası onun aynı zamanda iyi olanla hiçbir biçimde ilgilenmediğini de gösterir. Bir sanatı iyi ile ilişkilendirmek; neyi, neden ve niçin yaptığını bilmeyi gerektirir. Aş̧̧ı yaptığı işin nedenini veya niçinini ortaya koymadığından akıl-dışı (alogos) bir iş yapmaktadır. Oysa hekim kendi nesne alanındakilerin ne durumda olduğunu ve onlara uyguladığı her türden tedavinin nedenini bilir ve bu nedenle de akıl (logos) ile iş yapar. Tekhnê'nin akılla bağlantılı bir biçimde ele alınması ve nedenleri ortaya koyarak, nesnelerinin özünü ya da doğasını bilmesiyle ilişkilendirilmesi, onu aynı zamanda iyi ile ilişkilendirmektedir. Bu da tekhnê olarak adlandırılan her yapıp etmenin aynı zamanda etik bir temeli olduğunu da çağrıştırmaktadır (Aguirre 2016, 184).

Tekhnê'nin hazza dayalı olan ve bilgiyle yapılmayan işlerden farklı olduğunun vurgulanması, kavramın akıl ve bilgi ile bağlantılandırılması ve epistêmê ile ilgisinin araştırılmasını zorunlu kılar. Bu iki kavram arasındaki farklar incelendiğinde, tekhnê'nin Platon'un diyalogları içinde kimi zaman epistêmê ile anlam ortaklığı içinde kullanıldığı göze çarpar. Dolayısıyla Platon'un bilgi anlayışında gösterdiği çabanın epistêmê ile tekhnê'nin birbirinden tamamıyla farklı olduklarına işaret etmeye yönelik olmadığı aşikârdır.

- Peki, Thrasymakhos, sanatlar (tekhnai) hakimiyet kurarlar, sanat oldukları için daha güçlüdürler.

Thrasymakhos zorla kabul etti.

- Evet, dedi.

- O halde, her bilgi (epistêmê) kendiden üstün olanın faydasına olanı değil, yönetimi altında olanın yani güçsüzün işine geleni gözetir ve buyurur (Pl. Pol. 342c).

Platon I. kitaptaki bu konuşmada, tekhnê'yi, epistêmê'yle yer değiştirerek kullanmıştır. Bu durum diyaloğun başka kitaplarında da görülmektedir. Düşünür Politeia'nın VI. kitabında bölünmüş çizgi analojisinin tartışıldığı satırlarda çizginin üst kısmında yer alan dianoia kısmına dair açıklamasında, geometri (511b) alanını ve onunla benzer bilgi türlerini tekhnê olarak adlandırır. Analojide Platon sadece noêsis'e ilişkin olanı yani diyalektiği epistêmê olarak adlandırmaktadır. Ancak yine de Platon'un düşüncesinde tam anlamıyla bu türden bir genelleme yapmak, 349e-350a satırlarına bakıldığında çok da mümkün değildir. Bu satırlarda tam da tekhnê olarak adlandırılması beklenen (temel eğitim olan) müziğin hekimlikle birlikte şaşırtıcı bir biçimde bilginin formları içinde tanımlandığı yani epistêmê olarak ele alındığı görülmektedir. Kharmides diyaloğunda da pek çok diyalogda tekhnê olarak tanımlanan hekimlik epistêmê olarak tanımlanmaktadır. "O halde, hekimlik sağlığın bilimidir (epistêmê), değil mi (Pl. Kharm.165d)?”

Diyaloglar arasındaki bu kullanım farkı Platon'un dönemsel kullanımıyla ilgili olarak görülebilir. Ancak burada esasen Platon'un tekhnê'nin hiçbir şey bilmeden bir şeyler icra etmek olmadığ1 görüşünü kabul ettiği söylenebilir. Böylece filozofun şiirin ve rhetorikê'nin yerinin ne olduğunu, devlet düzenine en çok zarar verenin bunlar olduğunu göstermek açısından, tekhnê'nin sınırlarını (epistêmê' den ayırma ihtiyacı duymadan) çizme ihtiyacı duyduğu düşünüle- 
bilir. Bu nedenle tekhnê kimi zaman epistêmê ile benzer anlamda kullanılmaktadır.

Epistêmê kavramıyla ilgili en açık tanımlama, her ne kadar kavramları birbirinin yerine kullandığı eser de olsa, yine Politeia diyaloğunda mevcuttur: Bu biçimiyle epistêmê var olanların ne olduğunu, bulundukları duruma göre bilmektir (Pl. Pol. 478a). Bu da epistêmê'nin yalnızca ideaların bilgisi olarak belirlenmesi anlamını taşır. Bu açıdan tekhnê belli başlı faaliyetlerin nasıl yapıldığını/yapılacağını ortaya koyarken, bir diğer deyişle pratikle ilişkiliyken, epistêmê'nin teorik yan ile ilgilendiğini söylemek çok da yanlış olmayacaktır. Bu yüzden tekhnê'nin değeri epistêmê kadar önemlidir ve bir şeyi gnosis kavramı bağlamında anlamak veya kavramak ile ilişkilidir.

Tekhnê'nin bir sanatkâr tarafindan kavrandığının en önemli göstergelerinden biri, onun bütünüyle bilinmesidir. Bir diğer deyişle, bir tekhnê sahibi, sanatının konusuyla ilgili yalnızca iyi veya doğru konuşulanları değil, kötü veya farklı konuşulanları da ayırt etmek durumundadır. Ion diyaloğunda da sanata bütünüyle bakabilmenin ve sanatı diğer faaliyetlerden ayırmanın yolu olarak onu bütün yönleriyle ayırt etmek gerektiği ileri sürülür. Bir diğer deyişle, sanatkâr sanatının konusu olan nesne ile ilgili olarak iyi (arista) ve kötü (kakôs) konuşulanları ayırt edebilmelidir.

Sokrates: Peki, birçok kimse sağlıkl yiyecekler hakkinda konuşurken, bunlardan biri çok iyi konuşsa, bu çok iyi konuşanın çok iyi konuştuğunun, kötü konuşanın da kötü konuştuğunun farkına varacak olan iki ayrı kişi midir, yoksa tek bir kişi midir?

Ion: Tek bir kişsinin olacağı açık.

Sokrates: Kimdir o? Ne derler adina?

Ion: Hekim (Pl. Ion 531e).

Ion'un iddia ettiği üzere, kendisi bir sanata sahipse eğer, Homeros dışındaki şairler Homeros'un konuştuğu konularla ilgili birtakım şeyler anlattıklarında, onların iyi mi yoksa kötü mü konuştuğunu bilmesi gerekir. Ancak o, kendisinin de belirttiği üzere yalnızca Homeros'un konuştuğu konularda yetkinliğe sahiptir.

Sokrates: Sen yalnizca Homeros konusunda mi yetkinsin, yoksa Hesiodos ve Arkhilokhos'tan da aynı şekilde anlar misin?

Ion: Hayır, sadece Homeros konusunda yetkinim, Bu da bana yeter de artar bile.

Sokrates: Homeros'un ve Hesiodos'un aynı düşünceyi paylaştığ hiçbir konu yok

mu?

Ion: Hem de böyle bir sürü şey var.

Sokrates: Peki, böyle konularda Homeros’un söylediklerini Hesiodos’un söylediklerinden daha mi iyi yorumlarsin?

Ion: Bu konular üzerinde ikisini de ayn şekilde yorumlayabilirim, Sokrates, yeter ki aynı düşünceyi paylaşsınlar (Pl. Ion 531a-b).

Ion'un sözlerine göre kendisi Homeros'u ve Homeros ile aynı şeyleri söyleyen şairleri yorumlayabilir. Ancak teknê'ye sahip bir rhapsodos'un yalnızca şairlerin bir konu hakkında aynı şeyleri söyledikleri zaman değil, farklı şeyleri söyledikleri zaman da yorum yapabilmesi gerekir. Oysa Ion, yalnızca Homeros ile aynı konu hakkında konuşan bir şair eğer onunla aynı şekilde anlatıma sahip ise bu konuyla ilgili yorum yapabileceğini ileri sürmektedir. Hâlbuki tekhnê sahibi olan kişi aynı konu hakkında hem iyi hem de kötü bir biçimde konuşanı veya hem aynı hem de farklı şeyler söyleyeni kavrayıp, ayırt edip, yorum yapabilmelidir. Bir başka deyişle, rhapsodos bir tekhnê'ye sahipse, konuyla ilgili kendi yorumladığı şairden farklı bir şey öne süren başka bir 
şair varsa onu da anlayabilmelidir. Bu, o sanatı bildiğini gösteren önemli bir işarettir. Çünkü Sokrates'in de dediği üzere, tekhnê sahibi bir kimse iyi konuşanın farkına varabiliyorsa, kötü konuşanın da farkına varabilir (Pl. Ion 532a).

Tartışmanın sürdüğü satırlar arasında rhapsodos'un bir sanata sahip olup olmadığını göstermek için ele alınan konularda kimin yorum getirebilecek şekilde işinin ehli olduğu soruşturması da yapılır. Homeros ve Hesiodos ya da herhangi bir başka şair aynı konu ile ilgili iyi veya kötü, doğru veya yanlış ya da aynı veya farklı şeyleri konuştuğunda bunu ayırt edecek kişi bahsi geçen sanatı icra eden kişi olmak durumundadır. Örneğin, kehanet konusuyla ilgili aynı veya farklı şeyler söyleyen şairleri en iyi biçimde açılayacak olan kişi, ancak ve ancak işinin ehli olan kâhindir (Pl. Ion 531b). Sağlıklı yiyecekler, aritmetik vb. pek çok konuda ancak işin ehli olan insanlar konuşmaların iyi veya kötü olduğunu ayırt edebilenlerdir. Şairler bu konuları ele almış olsalar da, konulara ilişkin gerçek bilgi sahibi olanlar ne şairler ne de rhapsodos'lardır. Dolayısıyla bu kimselerin sahip oldukları her ne ise bunun tekhnê olmadığı açıktır.

\section{Rhapsodos'luk Nedir?}

Bir konuyu bilmek veya bir tekhnê'ye sahip olmak, onu her yönüyle ele almayı, farklı açılardan değerlendirebilmeyi gerektirmektedir. Bu yüzden yalnızca Homeros'un söylediklerini veya başka şairlerin fikirlerini yalnızca Homeros ile benzer düşüncelere sahip olduğu takdirde yorumlayabilen birinin, konuyu bütün yönleriyle ele aldığını söylemek zordur. Bu yüzden böylesi birinin tekhnê'ye sahip olduğu söylenemez. Bu kişi işini bilerek, kavrayarak veya anlayarak icra etmiyordur. Daha önce de belirtildiği üzere, bir tekhnê yalnızca tek bir şeyi konu alır. Bir diğer deyişle, şair veya rhapsodos'un icra ettiği gibi pek çok alanda bahseder, onlarla ilgili anlatımlarda bulunan veya kendine konu edinen bir tekhnê'den söz etmek mümkün değildir. Burada sözü geçen her bir alan ancak işinin ehli olan bir sanatkâr tarafindan yorumlanabilir. Ancak bir şairin veya rhapsodos'un bu konuların her birinde usta olduğunu söylemek makalenin daha önceki bölümünde özellikleri ayrıntılı şekilde anlatılan tekhnê tanımına da uymaz. Ancak Ion başarıyla gerçekleştirdiği bu performansının nereden kaynaklandığını ve neden sadece Homeros üzerine iyi konuşup da, diğer şairler hakkında hiçbir yorum yapamadığını bilmemektedir. Gelinen bu noktada Sokrates'e bunun ne anlama geldiğini sorar (Pl. Ion 532c) ve böylece Sokrates Ion'un tekhnê ile yapmadığı bu işi ne ile yaptığını ona anlatma firsatı bulur. Sokrates'e göre, tekhne bir bütündür (to holon) ve sanatkâr gerçekten bir sanatı yorumluyorsa, o sanatı icra eden herkesin sözlerini veya eserlerini aynı şekilde açıklayabilmelidir. Bir başka deyişı, bir hekim başka bir hekimin bir hastalık hakkında söylediği benzer veya farklı yorumları anlayıp kavrar; bunun üzerine konuşup yorum yapabilir. Oysa Ion'un performansı ve yaptığı işle ilgili anlattıkları bunu yapamadı̆̆ını göstermektedir.

Ion rhapsodos'luğu ne sanat ne de bilgi yoluyla gerçekleştirmektedir. Yaptığı işte başarılı olduğu ve ödül aldığı çok açıktır. Hatta Homeros'u ondan daha iyi yorumlayan başka kimsenin olmadığına hiç şüphe yoktur. Ancak bu durum onun rhapsodos'luğu sanat veya bilgi sahibi olmasından dolayı en iyi biçimde icra ettiği anlamına gelmemektedir. Sokrates, Ion'un theia dynamis/theia moira aracılığıyla işini yaptığını söyler ve bunu da Euripides’in Magnêsia, halkın da Herakleia diye adlandırdığı taşla bir analoji kurarak açıklar (Pl. Ion 533d).

Bu taş, sadece demir halkaları kendisine çekmekle kalmaz, aynı zamanda bu halkalara kendi gücünü katarak onların da aynı şekilde başka halkaları kendisine çekmesine neden olur. Hatta bazen öyle olur ki, birbirine geçmiş demir halkalardan uzun bir zincir ortaya çıkar ve her bir halka kendi gücünü o taştan alır (Pl. Ion 533d-e). 
Böylece şair, yorumcusu veya habercisi olduğu Mousa'lardan esinlenir; rhapsodos da şairin manyetik gücüyle yorumcunun yorumcusu ya da habercinin habercisi olur. Bu etki aynı zamanda seyircilere de geçer ve onlar da rhapsodos'un manyetik gücünün etkisi altına girer (bu, rhetorikê gücüne benzer bir büyü gücüdür). Bu esinlenme bir tür theia moira veya theia dynamis sonucudur ve sanat ya da akılla ilişkili değildir. Akıl olmaksızın gerçekleşen tanrısal bir paylaşımdır (Allen 1996, 5). Bu yüzden şair hassas, uçarı ve tanrısal bir varlıktır ve esinlenmeden ya da kendinden geçmeden yani aklı başındayken hiçbir şey yaratamaz (Pl. Ion 534a). Şiir denilen şey Mousa'ların bir icadıdır (Pl. Ion 534e). Mousa'lar şairi hangi konuya yönlendiriyorsa, şair o konuda konuşabilir veya şiir üretebilir. Rhapsodos'lar için de aynı şey geçerlidir. Mousa'lar onu hangi şairi yorumlamaya yönlendiriyorsa, o da ancak o şairle ilgili konuşabilir. Bu nedenle de Ion yalnızca Homeros hakkında konuşabilen, diğer şairleri yorumlayamayan bir rhapsodos'tur. Allen'ın $(1996,5)$ aktardığı üzere, işini bilerek yapmayan veya tekhnê ya da epistêmê' ye dayanarak açıklama getirmeyen insanların sahip olduğu bilgelik kâhinlerinkinden farklı değildir. Bu tür insanlar arasında Platon'a göre, rhêtorikê'ye hizmet eden politikacılar da vardır. Onlar da erdemlerini tanrısal bir ilham (theia moira) ile gerçekleştirirler.

Devlet adamlart polisleri idare etmekle meşguldürler ve bir bilgiyi kavrama karşısındaki durumları kahinlerde veya esinlenmiş kimselerden farkl değildir: bu kişiler ne söylediklerini bilmeden, esinlendiklerinde pek çok doğru şey söyleyebilirler, ... özellikle devlet adamlarını Tanrısal ve esinlenmiş kimseler olarak varsayabiliriz ... konuştuklarını hiç bilmedikleri için (Pl. Men. 99c-d).

Ion da tıpkı daha sonraki bir döneme tarihlenen Menon diyaloğunda politikacılar için söylendiği üzere, rhapsodos'luğu irrasyonel bir biçimde gerçekleştirmektedir. Şiir de rhêtorikê gibi bilgiyle iş yapmaz. Şiir kimi zaman şeyler hakkında doğru anlatılarda bulunuyor olsa bile bunu bilgiyle gerçekleştiremez. Şair tam bir bilgisizlik içinde, rhêtôr'lar gibi, ne söylediklerini bilmeden ve hatta farkında olmadan eser ortaya çıkarır. Platon için böylesi bir yaratma, yani şiir ve benzetme kullanan diğer etkinlikler, çoğu zaman bilgisizlikten daha da kötüdür (Pl. Pol. 602a-603b). Bu türden her yapıp etme irrasyonel duyguları harekete geçirmektedir (Pappas 1989, 386); bir diğer deyişle, ruhun kısımlarından en aşağı olanına etki etmektedir.

Ion'un icra ettiği performansın bilgisizlikle tanımlanmasından dolayı değer sahibi olmadığı görüşüne eleştirel bir yaklaşım sunan Pappas'a göre, Ion'un işi nadir de olsa bir açıdan uzmanlaşma biçimi olarak yorumlanabilir. Ion'un belli bir şairi yorumluyor olması, tam olarak bir tekhnê'ye sahip olmadığının göstergesi değildir. Rhapsodos'un sahip olduğu özel uzmanlık esasen tam olarak sanatı dışlamamaktadır. Bu yüzden de Pappas'a göre Ion'un bir sanata sahip olduğu iddia edilebilir (Pappas 1989, 384) ve Sokrates aslında bir yanlış anlama sonucunda Ion'u bilgisizlikle ve sanattan yoksun biri olmakla suçlamaktadır. Pappas'ın iddiasına göre, bir şeyin özel durumunu bilmekle genel durumunu bilmek arasında fark vardır. Örneğin Ion, sürücüye dair konuşmada, sadece Homeros'un konuya ilişkin söylediklerini bilir. Ancak genel olarak sürücülük fikrini bilmez. Bir diğer deyişle, Ion’un sadece Homeros'un satırlarını bilmesi onun genel bilgiye hiçbir katkısının olmadığı anlamına gelir. Sokrates ise bunu görmezden gelerek, her bir şiirde sürücü ile ilgili genel bilgiyi inceleme arzusundadır. $\mathrm{Bu}$ da onun şiirleri tek bir bilgi üzerinden, genel veya tümel olarak adlandırabileceğimiz bir bilgi türü üzerinden incelediğini gösterir. Sokrates'in şiirden beklediği bilgi ona göre şu şekilde özetlenebilir: Bir hekim Ilias'taki tıbbi bir tavsiyeye uyabilir veya onu reddedebilir. Ancak o bunu Ilias'taki amaçtan bağımsız olarak yapmalıdır (Pappas 1989, 385). Bir diğer deyişle, Ilias'ta anlatılan tıbbi tavsiyeye uyması, bunu Homeros'un dile getirmesinden dolayı değil, bu özel anlatıyı bilgiye dönü- 
ştürerek, sanatıyla ele almasından kaynaklanmalıdır. Yani onu daha genel bilgiye dönüştürmelidir. Ion ise, sanatlarla ilgili düşüncesini Homeros'un söylediği üzerinden, onun her anlatısını hakikatmişçesine ele alır ve sanatlara dair düşünceyi genellemez veya özel olandan tümel olana ulaşarak, onun üzerine düşünerek konuşmaz. Onun dünyayı anlama biçimi Homeros penceresindendir. Ion'un hatası Homeros'u tek hakikat olarak kabul etmesidir. Ancak Pappas'a göre bu durum onu tamamen sanat icra etmekten soyutlamamaktadır. Bir başka deyişle aslında Pappas, Platon'un şiire karşı eleştirel tutum geliştirmesinin ve onu ideal devlet modelinde hoş görmeyişinin nedeninin sadece bu sanatı icra edenlerin bilgisizliklerinden kaynaklanmadığını iddia etmektedir. Özellikle Politeia'da ele alındığı biçimiyle, bu problemin kaynağında, yani şiir ve buna benzer yaratımların başka birinin yerine geçerek, bir şeyi başka birinin ağzından anlatmasının temelinde, özel olanın genel olana dönüştürülememesi probleminin yattığı söylenebilir. Şair bize bir şeyi başka birinin ağzından oymuş gibi anlatır. Yerine geçtiği kişiyi taklit eder ve kimi taklit ediyorsa seyirciye onun dünya görüşünü sunar. Bir diğer deyişle bize tümel olanı değil, özel olanı sunar. Özel olanın seyirciye sunulması ve onu etkilemesindeki problem, özel olan durumun insanı melankoliye sürüklemesi ve sadece acı içinde kıvrandıracak olmasıdır (Pappas 1989, 386-388). Genel olanı düşünmek ruhun akılsal-olan (logismos) yanılyla ilgilidir ve sızlanmayı, acı duymayı, melankoliye kapılmayı engeller. Ancak ne zaman ki, şiirdeki örneğin ölümle ilgili kısmı, o andan çıkarak genelleştiremezsek, o zaman ruhumuzun akılsal-olmayan (alogiston) kısmının etkisi altında acılara gömülürüz (Pl. Pol., 604d). Bu yüzden Platon benzetmeci şairin ruhun akılsal yanıyla iş yapamayacağını düşünür (Pl. Pol. 605a). Pappas’a göre Platon için şiir genel olan üzerine düşünüş gerçekleştiremez. Onun bilgisizlik ile olan ilişkisinden ziyade ruhumuzun akılsal-olmayan yanına hizmet ediyor olması şiire karşı olan olumsuz tutumunun daha önemli bir göstergesidir.

Pappas'ın bu eleştirisine karşılık, şiirin ve buna benzer her türden icranın Platon tarafından eleştirilme nedeninin yalnızca söz konusu etkinliklerin ruhun aşağı kısımlarına hitap etmesi olarak belirlenemeyeceği söylenebilir. Çünkü şair veya rhapsodos'ların işi kendisine bilgi ve sanat eşlik etmediği için zaten ruhun akıllı kısmıyla ilişkili olamaz. Bilgisizlikle yapılan bu türden bir icra, ruhumuzun bizi melankoliye ya da acılara sürükleyecek kısımlarına etki edecektir. $\mathrm{Bu}$ nedenle Platon'un aslında bilgisizlikle değil, özeli tümelleştiremediği için şiirin insanları melankoli veya acıya düşürmesi yüzünden bu konuyla ilgilendiğini söylemek eksik bir açıklama olacaktır. Bilginin olmadığı yerde genel, genelin olmadığı yerde de acı ve melankoli vardır. Platon için tüm bu süreç birbiriyle bağlantılıdır.

\section{Sonuç}

Bu kısa ve Platon'a ait olup olmadığı tartışmalı olan diyalog filozofun bilgi anlayışıyla ilgili pek çok önemli noktaya ışık tutmaktadır. Daha sonraki diyaloglarla konular açısından ortaklık içinde olan bu diyaloğun, filozofun theia moira ve epistêmê/tekhnê arasındaki tartışmada Platon'un genel düşüncesini göstermede önemli bir yer tuttuğu açıktır. Diyalog daha önce de belirtildiği üzere, yalnızca estetik bir eser olarak değil, aynı zamanda Platon'un bilgi anlayışının habercisi olan erken ve sade bir deneme olarak görülebilir. Tekhnêlepistêmê tartışmasını bünyesinde barındırırken, bilhassa tekhnê' nin özelliklerini belirlemede kilit bir rol oynaması yine bu diyaloğun önemini göstermektedir. Zaten bu makalede de Ion diyaloğunun konusu itibarıyla diğer diyaloglarla bağlantılı olduğu kabulüyle tartışmalar yapılmıştır.

Homeros'u yorumlamada başarılı bir rhapsodos'un hikâyesini sunan Platon, onun işini bilerek mi, yoksa bilmeden mi yaptı̆̆ını ve tekhnê'nin her türden eser ortaya çıkarmakla ilgili olmadığını okuyuculara göstermeye çalışmaktadır. Şairlerin ve dolayısıyla onun etkisi altına girenlerin hassas, uçarı ve kutsal (tanrısal); onların da icralarını theia moira aracılığıyla gerçek- 
leştiği diyaloğun temel düşüncesidir. Platon bunu göstermeye çalışırken, tekhnê’ye ilişkin ortaya koyduğu özellikler, Ion'un bir sanatı olmadığını hatta şairlerin de icrasının sanat olarak adlandıramayacağını ortaya koymaktadır. Tekhnê, tek ve spesifik bir alanı kendine konu edinir, nesnesinin faydasını saptamaya çalışır ve bunu yaparken nedenini/niçinini gösterebilir. Oysa şairler ve Ion'un icrası bu özellikleri kendinde taşımaz ve onlar yalnızca kendilerinden geçerek irrasyonel yolla yaratımlarını gerçekleştirebilirler. Platon için şairlerin ve rhapsodos'ların bu durumu, günümüzde anladığımız manada tatı bir romantizm de değildir. Platon bunu daha çok aşağılayıcı bir tarzda kullanmaktadır (Pappas 1989, 381-382). Çünkü sanat veya bilginin konusu olmayan tüm etkinlikler insanda aşağı duygular uyandırır, bu da akılsal olandan uzaklaşma anlamına gelir. Platon için tanrısal olanın bilgisel açıdan değerinden bahsetmek de bu nedenle olanaklı değildir. Tanrısal olarak bahşedilmiş olan düşünülmemiş ve kavranmamış olandır. 


\section{KAYNAKÇA}

\section{Antik Kaynaklar}

Pl. Apol. ( =Platon, Apologia Sokratous) Kullanılan Metin ve Çeviri: Euthyphro, Apology, Crito, Phaedo, Phaedrus. Çev.: H. N. Fowler. London 1914 (Loeb Classical Library). Platon, Sokrates'in Savunması. Çev. E. Gören. İstanbul 2015.

Pl. Phdr. (=Platon, Phaidros) Kullanılan Metin ve Çeviri: Euthyphro, Apology, Crito, Phaedo, Phaedrus. Çev. H. N. Fowler. London 1914 (Loeb Classical Library).

Pl. Prot. (=Platon, Protagoras) Kullanılan Metin ve Çeviri: Laches, Protagoras, Meno, Euthydemus. Çev.: W. Lamb. London 2006 (Loeb Classical Library).

Pl. Men. (=Platon, Menon) Kullanılan Metin ve Çeviri: Laches, Protagoras, Meno, Euthydemus. Çev.: W. Lamb. Harvard London 2006 (Loeb Classical Library).

Pl. Grg. (=Platon, Gorgias) Kullanılan Metin ve Çeviri: Lysis, Symposium, Gorgias. Çev.: W. Lamb. London 1925 (Loeb Classical Library)

Pl. Pol. (=Platon, Politeia) Kullanılan Metin ve Çeviri: Republic 1-5. Çev.: P. Shorey. London (Loeb Classical Library)1930. Republic 6-10. Çev.: P. Shorey. London 1935 (Loeb Classical Library).

Pl. Ion (=Platon, Ion) Kullanılan Metin ve Çeviri: Ion (Şiir Üzerine). Çev.: N. P. Boyacı. İstanbul 2011.

Pl. Kharm. (=Platon, Kharmides) Kullanılan Metin ve Çeviri: Charmides. Alcibiades I and II. Hipparchus. The Lovers. Theages. Minos. Epinomi. Çev.: W. Lamb. London 1927 (Loeb Classical Library).

\section{Modern Literatür}

Aguirre J. (2016). “'Téchnê’ and 'Enthousiasmós’ in Plato’s Critique of Poetry”. Revista Portuguesa de Filosofia 72/1 (2016) 181-197.

Allen R. E. (1996). “The Ion Comment”. The Dialogues of Plato, Ion, Hippias Minor, Laches Protagoras (1996) 1-7. London.

Barchana-Lorand D. (2012). “'A Divinity Moving You’: Knowledge and Inspiration in Plato’s Ion”. Ed. A. E. Denham, Plato on Art and Beauty (2012) 84-105. UK.

Boyd T. W. (1994). "Where Ion Stood, What Ion Sang”. Harvard Studies in Classical Philology 96 (1994) 109-121.

Dorter K. (1973). “The Ion: Plato’s Characterization of Art”. The Journal of Aesthetics and Art Criticism 32/1 (1973) 65-78.

Gentile J. S. (2008). "Defending Ion: A Contemporary Rhapsode Replies”. Storytelling, Self, Society 4/2 (2008) 152-162.

Guthrie W. K. (1975). A History of Greek Philosophy IV Plato: The Man and His Dialogues Earlier Period. Cambridge 1975.

Kahn C. H. (1998). Plato and The Socratic Dialogue. Cambridge 1998.

Liebert R. S. (2010). “Fact and Fiction in Plato's Ion”. The American Journal of Philology 131/2 (2010) 179-218.

Moore J. D. (1974). “The Dating of Plato’s Ion”. Greek Roman and Byzantian Studies 15/4 (1974) 421-440.

Pappas N. (1989). “Plato’s 'Ion’: The Problem of the Author”. Cambridge University Press on Behalf of Royal Institute of Philosophy 64/249 (1989) 381-389.

Roochnik D. (1998). Of Art and Wisdom Plato's Understanding of Techne. Pennsylvania 1998.

Zeller E. (1888). Plato and Older Academy. London 1888. 